\title{
Exploring the Teaching of Communicative Grammar in EFL Classes in Benin to Promote Language Use in CBA Context
}

\author{
Estelle Bancolé-Minaflinou ${ }^{1, *}$ \\ ${ }^{1}$ Department of English, Faculty of Letters, Language and Communication, Abomey-Calavi, Republic of Benin \\ *Correspondence: Department of English, Faculty of Letters, Language and Communication, Abomey-Calavi, \\ Republic of Benin. E-mail: bankestelle@yahoo.fr
}

Received: September 18, 2018

doi:10.5430/wje.v8n6p58
Accepted: November 15, 2018 Online Published: December 10, 2018

URL: https://doi.org/10.5430/wje.v8n6p58

\begin{abstract}
This paper sets out to investigate how communicative grammar can effectively be used in EFL classes in Benin to promote real language practice. To collect data, instruments such as questionnaires, interview and class observation were used. The sample of the study consists of twenty purposively chosen secondary EFL teachers (ten of them teach traditional grammar and ten, communicative grammar) and twenty six students ranging from beginners to advanced level. The data were analyzed using the SPSS tools, the goal of which is to verify the effectiveness of this approach over the traditional one.

The findings of the investigation have revealed the following: (i) not many teachers teach communicative grammar in Benin and those who claim they teach it still have a hazy idea of what it is supposed to be; (ii) communicative grammar teaching is what is needed to make EFL learning a rewarding experience for students' effective use of the language; (iii) both approaches are not mutually exclusive for they can become perfect complements.

The study concluded with some strategies for implementation illustrated by some suggested activities that can develop students' communicative strategies and interactional skills.
\end{abstract}

Keywords: traditional grammar, communicative grammar, communicative language teaching, language use

\section{Introduction}

Teaching EFL for communication in a francophone country in general and teaching its grammar for communication is apparently a real challenge. Teaching the four skills for communicative purpose looks like a plausible idea. But how can teachers make grammar teaching traditionally considered as a set of rules to apply to form correct sentences communicative, deserves a close attention. For this purpose, this paper aims to highlight the advantages of using the communicative approach in the traditional English grammar teaching in EFL classes in Benin so as to make it more interactive and productive.

In fact, though many people, mainly some English practitioners misunderstand the term communicative language teaching (CLT), thinking that students can speak the language without bothering to follow any rules, many also believe that this approach stands the chance to provide students with necessary skills that would make them communicatively efficient. Richards (2006) opined that "CLT can be understood as a set of principles about the goals of language teaching, how learners learn a language, the kind of classroom activities that best facilitate learning, and the roles of teachers and learners in the classroom". In other words, it means promoting the teaching of communicative competence which is nothing but giving students the means to use language appropriately, both receptively and productively.

Richards and Rogers (2010) went further to highlight that "language learning is best served when students are interacting, completing a task, learning content or resolving real life issues as the goal of language is to develop communicative competence". What is then the place and role of grammar in this approach that views language as an instrument for communication?

Therefore, this study has used the following research questions as sign-posts.

1. What are the challenges the teaching of grammar has been currently facing in EFL classes in Benin? 
2. How far can the teaching of communicative grammar improve the teaching of EFL for learners' effective language use in real life?

This paper will try to address the issue by revising the current situation of grammar teaching in EFL classes in Benin so as to help teachers put focus on communication related to the realistic use of language in real life situations. The main purpose is to raise trained and untrained teachers' awareness of the importance of teaching grammar within context, using communicative processes in a holistic view of EFL learning.

\subsection{Background to the Study}

The international dimension of the English language has given EFL teaching a more potentially significant role that goes beyond the traditional ethnocentric views of the language. Therefore, the challenge of using this language as a tool that opens windows to the world and to many opportunities has given a new thrive to its teaching/ learning even in a country like Benin where it is used as a foreign language. In this part of the world, though some efforts have been made to make the teaching/learning of the language relevant to the needs of the country and meet up with the current challenges, many things remain to be done at the classroom level.

Lack of adequate materials such as textbooks, audio-tapes, video-tapes and libraries is compounded by lack of qualified teachers, able to exercise critical judgment of innovations in language teaching. Whether in rural or urban areas, large size class impacts negatively on the quality of the teaching/learning and assessment processes. Mechanical tests for a long time have pervaded the system and usually deal with reading comprehension activities, writing and grammar tests while speaking and listening are simply ignored.

In their quest to remedy this bleak situation, the educational authorities in the early nineties have adopted a learner-centered teaching methodology: the Competency-Based Approach (CBA). Let us shed some light on this new approach being implemented for some years now.

\subsection{Competency-based Approach}

The approach bears great expectations for a whole society which, at some time, has felt the need to adapt its educational system to the global changing economic environment, characterized by high demands on the individual, on peoples and on societies. The CBA focuses on the development of practical life-skills in the learners across all the subjects taught in the school. Teaching in the new approach takes place through three main groups of competencies which are the transversal, the tran-disciplinary and the disciplinary competencies. In English for example, there are three basic disciplinary competencies to develop in learners through the teaching/learning/evaluation processes. The main purpose is that:

Learners should be able to communicate orally in English (speaking skill);

Learners should be able to make their personal opinions about texts or messages they have read or listened to (reading and listening skills);

Learners should be able to write texts of varied technical types and functions. (Writing skills) [DIP, 2010]

The main objective of this program is to link classroom experience to the learners' socio cultural environment so as to motivate them to become true agents of change and development. It aims at responding to the needs of the country while providing generic competencies including skills, values and attitudes to all learners. This program has been putting extra burden on teachers for it requires an acute imagination and creativity difficult to face by an untrained teacher because it assigns him a new profile just as complex as diverse. Obviously, the role of the EFL teacher is more than ever daunting in this era of CBA. These multiple demands on him/her require adequate training in many areas including updated pedagogical issues in language teaching/learning. However, it is clearly demonstrated in this field, that no program can be effective if capacities are not built in teachers to promote news ways of performing their professional roles. Hence, the necessity of finding new ways of teaching grammar so as to promote communication to meet the current requirement. Some training sessions mentored by the researcher have started introducing this approach on her courses so as to create in teachers the awareness that new ways should be found to teach grammar in context.

Many researchers and language educators have highlighted the issue by providing various views that need scrutiny.

\subsection{Literature Review}

The role of grammar in language teaching has always constituted a very important and debated issue mainly in foreign language context. Traditionally, grammar was considered as prescriptive, that is by telling people what rules they should know and how they should speak and write and this includes many aspects of linguistic knowledge. But 
the teaching of grammar for the past decades has undergone a substantial change in people's traditional attitudes and approaches. Today, more and more teachers as Celce-Murcia (1991, p. 460) have begun to pay attention to the spoken English and discourse structure, making out between language use and language usage.

As for Lock (1997, p.267) he identified some of the dichotomies that arise whenever dealing with grammar teaching, which are forms versus function, forms versus meaning, fluency versus accuracy, meaning-based instruction versus form-based instruction, and the one that denies grammar teaching, that is communication versus grammar. From these dichotomies, Newby (2003) managed to sort things out by presenting three general ways of approaching grammar throughout ELT history: traditional grammar teaching, communicative language teaching and post-communicative approaches. Let's highlight each of these approaches.

\subsubsection{Traditional Grammar Teaching}

According to Doughty and Williams (1998), traditional grammar focuses on the learning of technical vocabulary for nouns, verbs, adverbs and adjectives; learners are taught grammatical rules to master sentence patterns. It means at classroom level that, a teacher explicitly presents to students a grammar rule followed by a practice exercise to apply the rule. The chance of drawing an incorrect form of the language is then minimized.

Ellis (1995) and Larsen-Freeman (1991) discovered that this type of language learning, despite its facilitative effects stands less chance of impacting on language acquisition whereas for Ulrich (1994) the teaching of grammar should include three components: language structure, meaning and use. In fact, an important characteristic of traditional language teaching is that not much or even no emphasis is put on learners' communicative needs in real life situations but rather on their classroom immediate needs or just to satisfy exams demand. In Benin, the classroom teaching has unfortunately been more exam-oriented than catering for students meaningful practice. As a result, learners often have difficulty using what they have learned beyond the classroom setting. It is for this reason that Skehan (1996) is of the view that though mechanical practice may be of little help to effective grammar use, precise focus on a particular form can benefit students.

However, it seems wise not to radically discard the traditional methodology but to combine it with the new communicative teaching methodology for all they can offer the CBA in a roundabout way.

\subsubsection{Communicative Language Teaching (CLT)}

The CLT which appeared in the eighties has changed the world of foreign language teaching and has gone beyond linguistic theories. Richards (2006, p.23) contends that "It describes a set of general principles grounded in the notion of communicative competence as the goal of second and foreign language teaching. A new approach that has evolved as our understanding of the processes of second language learning has developed."

Lopez \& Agullo (2013) argued that the main objective of CLT is to teach communicative competence, which includes the knowledge of the construction blocks of sentences (e.g. parts of speech, tenses), a teaching methodology which refers to some aspects of language such as making use of language for various purposes and functions, varying them in taking account of the setting and the audience for instance, differentiating between formal and informal, written and spoken discourse etc. Many researchers shed light on the issue of CLT and offered various enlightening views.

In highlighting the key principles of CLT, Brown (2001) presents the following six characteristics. i) Classroom goals refer to all the components (grammatical, discourse, functional, sociolinguistic) of communicative competence. ii) Language techniques aim at involving learners in the pragmatic, authentic, and functional use of language that leads to meaningful purposes. iii) There are two complementary principles that underlie communicative techniques: fluency and accuracy alternatively used by students, depending on the meaning of the communication. iv) Language in a CLT class is used productively and receptively, and in impromptu speeches in real life situations. v) Students are the main actors in the building of their knowledge as opportunities and strategies are given to them to understand their learning styles and use them appropriately. vi) Teachers are no longer considered as the fountain or the only source of knowledge but have to play the role of facilitator and guide by encouraging students to be responsible for their own learning through authentic interaction.

These key principles are consistent with the (CBA), a socio-constructivism approach centered on the learner and which focuses on acquiring life-coping skills while developing the language to perform the skills. However, a "weak" and a "strong" version of CLT are classified by Ellis (2003). For him, the weak version considers that identified communicative competence components can be taught by providing learners with opportunities in skills integration programs, the main goal is learning the language for communicative purposes in and outside the classroom. A contrastive view reveals a strong version of CLT. Howatt (1984) disagrees with the beliefs of students' acquisition of 
structural components of language used later for communication, but rather emphasizes on teachers making students familiar with various communication opportunities to be used in real life.

As far as in the early eighties, a supporting view from Littlewood (1981) had this to offer about CLT "it gives planned emphasis on functional as well as structural features of language, combining these into a more completely communicative view". It means that an important aspect of CLT includes that teachers provide learners with meaningful opportunities to build up their communicative competence through interactive activities. To probe a bit further, Richards (2006) unveiled CLT interactive dimension by showing its four advantages: i) students are exposed to the language uttered by other members of the group; ii) more language is available for use than in any other approach; iii) it makes motivation rise gradually; iv) fluency is developed more importantly through the learners' exposure to authentic materials. He even went further to suggest that a CLT classroom is likely to make students feel secure, unthreatened and non-defensive and as a result, can avoid taking on a teacher-centered authoritarian attitude.

Nevertheless, the major known disadvantages of the CLT seem to be: i) the role of grammar in language learning is down played. ii) Communicative tasks are not easy to design mainly when teachers are not trained or not appropriately trained. iii) The role and expertise of the teacher are confusing. iv) Too much responsibility is put on learners. v) The curriculum is often unbalanced; therefore, not many textbooks can really help teach CLT because of lack of authentic materials. Some writers identified rightly or wrongly other weaknesses. Rama and Agullo (2012) identified the following deficiencies: a queer language ridden with grammatical mistakes, difficult to get rid of because the correction is most of the time selective. Furthermore, students may lack the necessary metalinguistic and analytical skills that could make them autonomous language learners, and help them understand sophisticated texts and prepare them for professional or academic life.

Obviously, the pros of CLT outweigh its cons as it offers a wide range of undeniable support to CBA and consequently many advantages Beninese learners can really tap from. Let's now shed light on what is meant by communicative grammar and its place in CLT.

\subsubsection{Communicative Grammar (CG)}

Highlighting the role of grammar within the CLT can be controversial because some researchers believe that it does not include any grammar but has an exclusive focus on meaning while others think it still encompasses a strong grammar basis made of incorporated grammatical points. Thornbury (1999, p.18-19) to clear up the misconception distinguished two main types of approaches to CLT: the shallow-end approach and the deep-end approach. The former, encourages the use of communicative language through grammatical rules and their application in situation. In fact, it is an inductive way which does not make use of rote-learning of grammatical rules but rather encourages teachers to provide examples from which learners infer rules. Rutherford (1996) calls it consciousness-raising. The latter, the deep-end approach to CLT refers to the unconscious acquisition of grammar in communicative contexts without any previous and explicit teaching. This approach is in line with Krashen's theory (1985) of Natural Approach. Unfortunately, this model proves inadequate as learners' competence suffers from lack of accuracy and fluency and most teachers feel uncomfortable not to teach grammar for communicative purposes.

To overcome this dichotomy, post-communicative approaches researchers such as Skehan (1998), contended for the integration of both models by arguing that conscious knowledge can become unconscious and vice versa.

However, within these approaches some most commonly known ones are:

Task-based teaching; Focus-on-form teaching; Content-based instruction and Cooperative language learning (Newby, 2006). All these forms support the view that explicit grammar and communicative processes can go hand in hand. Harmer (1997, p.7) exemplified this by putting it this way: "at this stage, it is enough to say that grammar teachingof both the overt and covert kind- has a real and important place in the classroom". Moreover, it is obvious that research work on the teaching and learning of EFL/ESL has helped today to view grammar as one of the component of communicative competence and as a tool to foster oral and written forms for communicative purposes rather than focusing on grammar at the sentence level. So, teaching communicative grammar means helping students internalize rules and patterns not in isolation but to serve social functions in contexts, either inductively or deductively by taking account of students' need, objectives, educational level, learning styles, error correction techniques, effective communicative activities and authentic tasks [Larsen-Freeman, (1991)].

With this theoretical framework in mind, and because of the limited or absence of empirical research that can illuminate the issue of grammar teaching in Benin, the rationale for this study is to help Beninese EFL teachers be aware that CBA can benefit a lot from CLT and as a result, help them improve their grammar lessons. Another justification is to solve the dichotomy among the teachers about the type of grammar that really fits CBA and is 
likely to meet its objective. Research-enlightened choices need to be made.

\section{Method}

By raising teachers' awareness to the teaching of communicative grammar that can meet students' learning goals, the current study is exploratory in nature. It first checks the challenges faced by Beninese teachers to teach EFL for real life communication, and more importantly how communicative grammar teaching can be a contributing factor to improve students' effective language use. For this purpose, quantitative and qualitative methods are used: questionnaire administration, class observation and interviews are held to the main stakeholders (teachers, students and supervisory staff) to elicit opinions and have a clear view of the teaching/learning process in relation to the issue at stake.

This section is split into subsections dealing with the study sample, the research instruments, the validity and reliability of these instruments and the procedure used for data collection and analysis.

\subsection{Sample}

Two types of secondary school teachers were purposively chosen: those who use the traditional methods to teach grammar and those who claim they teach it communicatively [Ten (10) respondents in each category]. Twenty six students, randomly selected from each category of teachers were to fill in questionnaire. Two teachers, a trained and a being trained one were selected to be observed by the investigator herself. Three teachers and a supervisory staff were also sampled for interview.

\subsection{Instrumentation}

\subsubsection{Interview}

The choice of interview in this study is supported by the view of researchers such as Kvale, (2007, p. 11) who argued that it is "a uniquely sensitive and powerful method for capturing the lived experiences and lived meanings of the subjects' everyday world". Similarly, Scott \& Usher, (2006, p.147) contended that its aim is: "to seek in-depth understanding about the experiences of individuals and groups, commonly drawn from a sample of people, selected purposively. Such types of interviews are called semi-structured".

The current study has used qualitative methods for data collection. Three semi-structured interview questions designed by the researcher herself were asked to three teachers and a supervisory staff to explore their perceptions, opinions and attitudes in a face-to-face individual audio-taped interview with the researcher. Each of them voiced his/her perceptions and attitudes about the current situation. Some questions, probes, prompts and intuitive questions were framed, enlightened by the investigator's own experience as a teacher trainer. Each interview lasts twenty to thirty minutes. This open-ended interview method was designed to minimize the limitations of the self-completion questionnaire method. The questions are as follows: (1) How is grammar taught in our EFL classes today? (2) What do you think of communicative grammar teaching being generalized in Benin? What suggestions can you offer to make grammar teaching consistent with our students' communicative needs today?

\subsubsection{Questionnaires}

\section{* Students' Questionnaire}

The students' questionnaire is made up of ten items designed by the investigator. It deals with: years of learning English; level in English; type of grammar being taught; reasons for liking or not the way grammar is taught; degree of ability to apply grammar rules to oral communication and to written forms; ability to use, or adapt grammar to real life situations; involvement in interactive meaningful communication during grammar lessons; and grammar lessons help to interaction with the outside world.

\section{* Traditional Grammar Teachers' Questionnaire}

Sixteen items have shed light on this questionnaire. They are as follows: teachers' length of service and training; importance and reasons for teaching grammar and mainly traditional grammar; relationship and degree of relationship between CBA (Competency-Based Approach) and CLT; ways of teaching grammar; separation or integration and their degree; approach used (inductive or inductive or both); time of teaching grammar; challenges and suggestions for improvement.

\section{* Communicative Grammar Teachers' Questionnaire}

This questionnaire consists of sixteen items designed by the researcher. Apart from question eight (8) about the way grammar is taught and question fifteen (15) about the challenges in teaching communicative grammar, both 
questionnaires are the same though different answers were expected of them. No previous information was provided to the participants before they were offered the questionnaire which is nothing but an attempt to preserve their original views.

\section{* Class Observation Guide}

Two teachers, a trained and a being trained ones, supposed to be teaching communicative grammar were kindly requested by the investigator to present a learning situation with a grammar lesson sequence. The objective is to have a balanced view of the problem. To avoid gathering extraneous data and taking into account the aim of the study, the following items were to be observed: type of grammar presented (traditional? Communicative?); approach (inductive? deductive?); integration or separation from classroom texts or tasks? Strategies used? Time to present the grammar sequence?

\subsection{Instruments Validity and Reliability}

For the validity and reliability of the instruments to be used, the researcher discussed the issue at stake with some experienced E.F.L teacher trainers and inspectors. They were asked to judge the appropriateness and relevance of each instrument item for the overall purpose of the study. This led to the reformulation of some items for clarity and conciseness sake.

\subsection{Procedure for Data Collection and Analysis}

Participation was voluntary and respondents after completion of questionnaire or involvement in interview or class observation were given additional information about how their answers would be used with guarantees of confidentiality and anonymity. The collection of data lasted two weeks to allow teachers time to reflect carefully before responding to the questionnaire. The descriptive statistics, Statistical Package for Social Sciences (SPSS) software was used to work out frequencies, percentages and cross-tabulations according to the nature of the items. All the data have highlighted the two main research questions.

\section{Results}

The results of this study have shed light on both research questions. They are presented, analyzed and interpreted.

\subsection{Presentation Results}

\subsubsection{Students' Results}

In regard to general information, most of the students have been learning English for about five years. When asked to identify their level of English (61.5\%) mentioned they were intermediate students and only $15.4 \%$ considered themselves advanced. Eighty eight point five percent (88.5\%) dislike the way they have been taught grammar and $96.2 \%$ claimed that they are taught traditional grammar. Nonetheless, opportunity is given to them to spot the positive points in this type of grammar.

In the following figure, the years these students have spent learning English are cross tabulated with the advantages they identified in traditional grammar teaching.

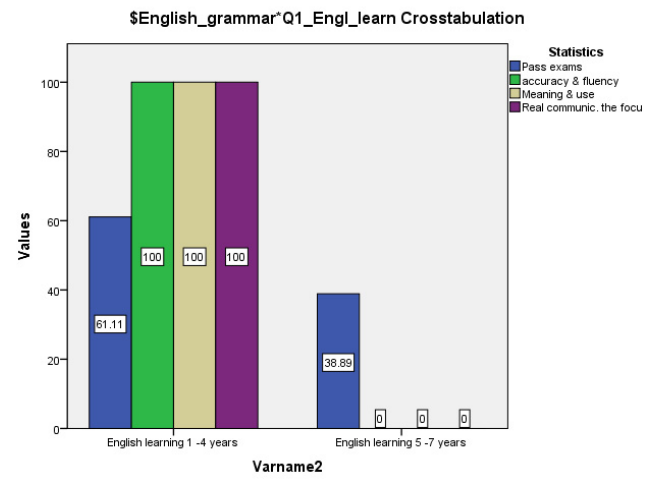

Figure 1. Cross Tabulation of Students' Years Spent Learning English and Advantages in Traditional Grammar 
The results in the figure show that nearly all the students of the first cycle (1-4 years) mentioned what they consider as advantages in traditional grammar: 'it provides opportunities to develop accuracy and fluency', 'to know sentence patterns, meaning and use' and 'makes real communication the focus of language learning'. Sixty one point eleven percent of them $(61.11 \%$ struck the item 'to pass exams' which is also the only reason why advanced second cycle students (5 -7 years) have been learning grammar (38.89\%). This is understandable if one knows that the national exams and even classroom tests are heavily loaded with prescriptive grammar.

As it can be expected, the students have also ground for complaint.

In the following figure, attempt is made to cross tabulate the years students have spent learning English and the reasons why they dislike the way grammar is taught to them.

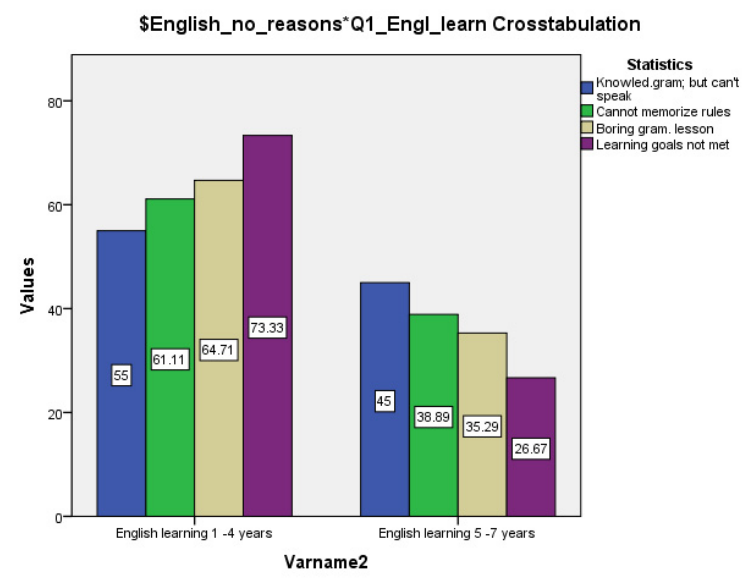

Figure 2. Cross tabulation of Years Students Spent Learning English and the Reasons Why They Dislike the Way English is Taught

The results in figure 2 reveal that both categories of students do not have the same acute awareness of the problem. More first cycle students or post-beginners (1-4 years) than advanced students seem interested in showing the reasons of their grievances: 'I know grammar rules, but I can't speak English (55\% against 45\%); 'I cannot memorize rules and apply them correctly is my problem'(61.11\% against $38.89 \%)$; 'grammar lessons are often boring because of lack of interaction and involvement'(64.71\% against $35.29 \%)$ and 'learning goals are not met' ( $73.33 \%$ against $26.67 \%$ ).

The students were also given the opportunity to appreciate their ability to apply grammar rules to oral and written communication. The following table shows the outcome.

Table 1. Ability to Apply Grammar Rules to Communication

\begin{tabular}{ccccc}
\hline $\begin{array}{c}\text { Grammar and } \\
\text { communication }\end{array}$ & Frequency & Percent & $\begin{array}{c}\text { Valid } \\
\text { Percent }\end{array}$ & $\begin{array}{c}\text { Cumulative } \\
\text { Percent }\end{array}$ \\
\hline very good & 1 & 3.8 & 3.8 & 3.8 \\
Somewhat good & 15 & 57.7 & 57.7 & 61.5 \\
Not good at all & 10 & 38.5 & 38.5 & 100.0 \\
Total & 26 & 100.0 & 100.0 & \\
\hline
\end{tabular}

It can be seen that $57.7 \%$ struck 'somewhat good', whereas $38.5 \%$ 'not good at all' and only $3.8 \%$ mentioned 'very good'. So, the relevance of the teaching of grammar for communication sake is not to be demonstrated.

In the same vein the $84.6 \%$ of them confessed that they are not able to transfer grammar lessons to real life situations and the same percentage declared that grammar sessions are far from being arenas of interactive and meaningful communication. Similarly, $57.7 \%$ of them admitted that grammar lessons are not helping them interact with classmates and English speaking people outside. 


\subsubsection{Traditional Grammar Teachers' Results}

This is the training situation of this category of teachers.

Table 2. Training Situation

\begin{tabular}{lllll}
\hline Training situation & Frequency & Percent & $\begin{array}{l}\text { Valid } \\
\text { Percent }\end{array}$ & $\begin{array}{l}\text { Cumulative } \\
\text { Percent }\end{array}$ \\
\hline Trained & 3 & 30.0 & 30.0 & 30.0 \\
Untrained & 2 & 20.0 & 20.0 & 50.0 \\
Beingtrained & 5 & 50.0 & 50.0 & 100.0 \\
Total & 10 & 100.0 & 100.0 & \\
\hline
\end{tabular}

Obviously, the training situation is hardly glowing as half of the respondent teachers is being trained. Eighty percent $(80 \%)$ of this same category of teachers admitted that grammar is very important whereas $20 \%$ mentioned it is somewhat important. The same proportion found out that CLT is closely related and somewhat related to CBA, but not helping it to a great extent.

Some attempt was made to cross tabulate this category of teachers' years of service with their reasons for teaching grammar.

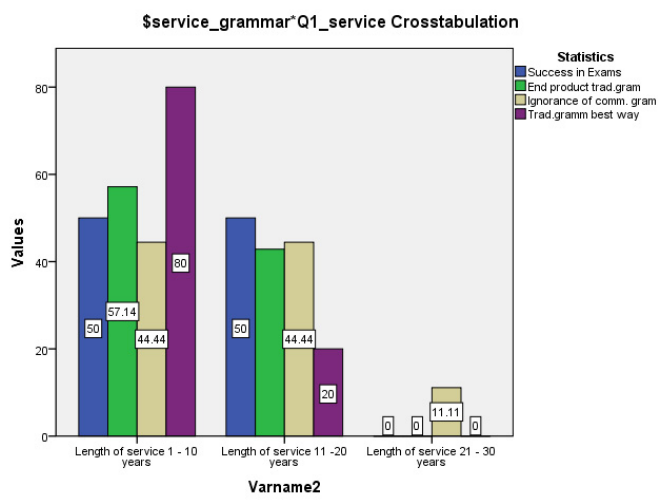

Figure 3. Cross Tabulation of Years of Service and Reasons for Teaching Grammar

The figure shows that relatively younger teachers in the profession than mature ones ( $1-10$ years) found that their main reason for teaching grammar is that it is the best approach $(80 \%)$. This is followed by $57.14 \%$ of those who found it difficult to shrug off the weight of tradition, being themselves the end-products of traditional grammar. For $50 \%$ of them, their students' success in exams is their main reason for teaching TG. It cannot be otherwise if we know that national exams and tests are heavily loaded with prescriptive grammar. Ignorance of what TG stands for is an equally shared hurdle by young and mature teachers.

It is however enlightening to know how these teachers teach grammar. This is shown in table three (3).

Table 3. Strategies for Teaching Grammar

\begin{tabular}{lccc}
\hline \multirow{2}{*}{\multicolumn{1}{c}{ Strategies for teaching grammar }} & \multicolumn{2}{c}{ Responses } & Percent of \\
\cline { 2 - 3 } & $\mathrm{N}$ & Percent & Cases \\
\hline Rules and explanations & 10 & $30.0 \%$ & \\
Presentation-practice- production & 8 & $26.7 \%$ & $88.0 \%$ \\
Controlled. exercises and drilling & 5 & $16.7 \%$ & $55.6 \%$ \\
Explicit knowledge of rules & 8 & $26.7 \%$ & $88.9 \%$ \\
$\quad$ Total & 31 & $100.0 \%$ & $333.3 \%$ \\
\hline
\end{tabular}

These results reveal that most of these teachers have been teaching grammar the real traditional ways that is 'through rules and explanations', 'presentation-practice-production', 'controlled exercises and drills' etc. As a result, $80 \%$ of them rightly confessed that they separate grammar from other classroom tasks, whereas the same proportion $80 \%$ 
mentioned the integration with other skills is minimal and $40 \%$ of them mentioned that this separation has not been helping their students.

Inductive and deductive approaches are equally used (50\%) by the respondent teachers. Moreover, as it can be expected, their challenges are daunting. Table 4 lists them.

Table 4. Challenges

\begin{tabular}{lccc}
\hline & \multicolumn{2}{c}{ Responses } & Percent of \\
\cline { 2 - 3 } \multicolumn{1}{c}{ Challenges } & $\mathrm{N}$ & Percent & Cases \\
\hline Knowing grammar; but can't speak English & 10 & $31.0 \%$ & $100.0 \%$ \\
Learning goals not reached & 5 & $17.2 \%$ & $55.6 \%$ \\
Needs \& interests not met & 7 & $24.1 \%$ & $77.8 \%$ \\
Lack of confidence & 8 & $27.6 \%$ & $88.9 \%$ \\
\hline
\end{tabular}

The main challenges are obvious. Students know grammar but they cannot speak the language; their learning goals, needs and interests are not met and they lack confidence. As a result, the respondent teachers provide some suggestions presented in table 5 .

Table 5. Suggestions

\begin{tabular}{lrrr}
\hline & \multicolumn{2}{c}{ Responses } & Percent of \\
\cline { 2 - 3 } \multicolumn{1}{c}{ Suggestions } & N & Percent & \multicolumn{1}{c}{ Cases } \\
\hline Nation-wide training & 10 & $25.6 \%$ & $100.0 \%$ \\
Exams format change & 9 & $23.1 \%$ & $90.0 \%$ \\
Regular training a priority & 10 & $25.6 \%$ & $100.0 \%$ \\
Provision for teaching materials & 10 & $25.6 \%$ & $100.0 \%$ \\
Total & 39 & $100,0 \%$ & $390,0 \%$ \\
\hline
\end{tabular}

The challenges are revealing of the awareness of the respondents to make the teaching of grammar relevant to the main goals of English teaching in Benin. Therefore, nearly $100 \%$ of them focused on: nation-wide training, regular in-service, provision for teaching materials and exams format change.

\subsubsection{Communicative Grammar (CG) Teachers' Results}

Just like respondents who teach TG, CG teachers' years of service were cross-tabulated with their reasons for teaching grammar. This is presented in figure 4.

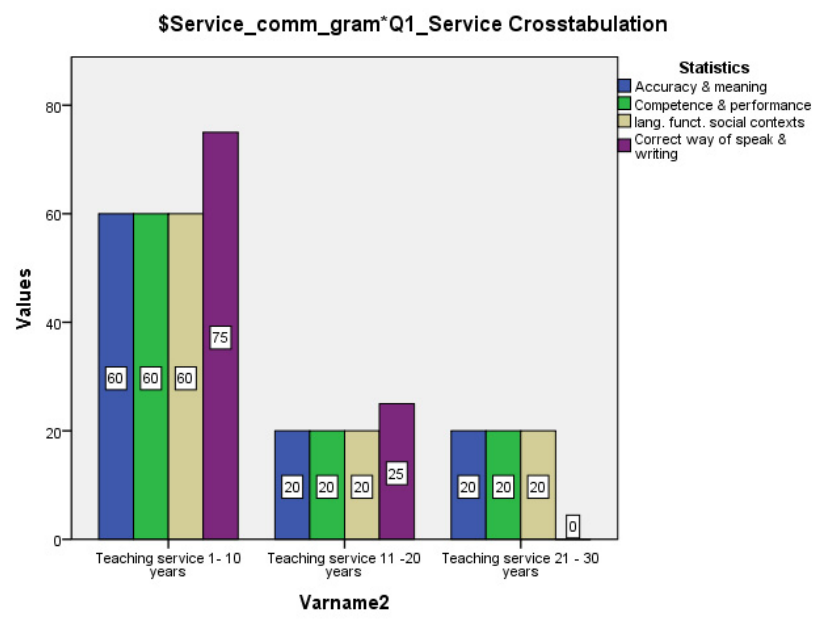

Figure 4. Cross Tabulation of Years of Teaching English and Reasons for Teaching Grammar

Obviously, younger teachers ranging from 1 to 10 years seem to have strong reasons to teach grammar than matured 
teachers from 11 to 30 years of teaching service. This is unexpected because experienced teachers are normally supposed to show more interest in teaching for more effective results.

Knowing why this category of teachers has chosen to teach communicative grammar is very important. Therefore, effort was made to cross tabulate their years of teaching with their reasons for teaching communicative grammar. The outcome is presented in figure 5

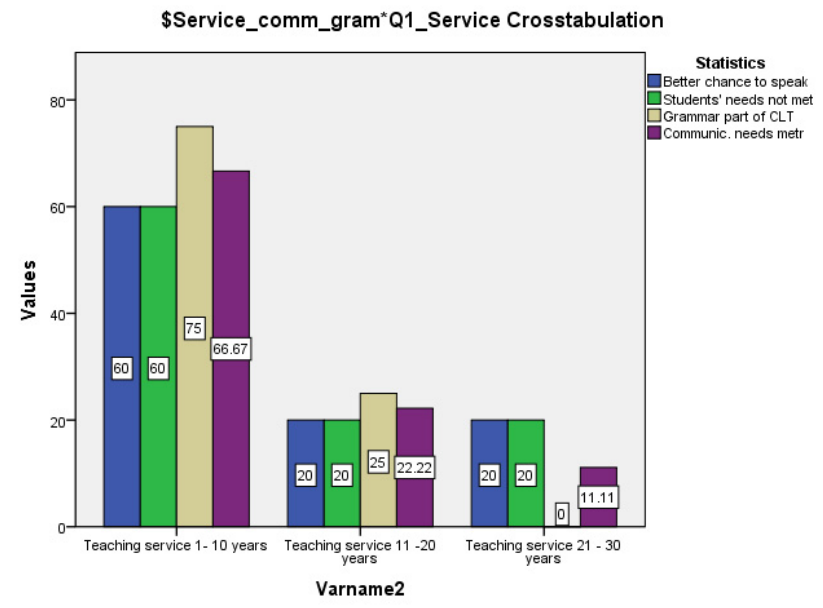

Figure 5. Cross tabulation of Years of Teaching English with Reasons for Teaching Communicative Grammar

It is striking to observe that younger teachers ranging from 1 to 10 years seem to have stronger reasons to teach communicative grammar than matured teachers from 11 to 30 years of teaching service. This is unexpected because experienced teachers are normally supposed to show more interest in teaching for effective results than young ones.

The reasons why these respondents have chosen to teach grammar communicatively are revealing of their teaching goals, that is teaching the language for communication purposes. These are: 'teaching grammar should be part and parcel of CLT' (75\%); 'the communicative needs of students for real life situations are met' (66.67\%); 'better chance is offered to students to speak the language' $(60 \%)$ and finally 'traditional grammar teaching has failed to meet students' needs'. For all these reasons $60 \%$ of them recognized that CBA and CLT are closely related though $40 \%$ found out that CLT has not been helping much CBA. These data are similar to what traditional grammar teachers mentioned about the issue. Once again, younger teachers than older ones show more concern about the issue of teaching grammar for communication.

However, the different strategies this category of teachers mentioned they use to teach grammar are revealed in table 6.

Table 6. Strategies for Teaching Grammar

\begin{tabular}{lccc}
\hline \multirow{2}{*}{\multicolumn{1}{c}{ Strategies for Grammar Teaching }} & \multicolumn{2}{c}{ Responses } & Percent of \\
\cline { 2 - 3 } & $\mathrm{N}$ & Percent & Cases \\
\hline Focus on forms and meaning & 10 & $28.6 \%$ & $100.0 \%$ \\
Opportunity for accuracy and fluency & 10 & $28.6 \%$ & $100.0 \%$ \\
Grammar integration. of four skills & 10 & $28.6 \%$ & $100.0 \%$ \\
Use of traditional and communication Grammar & 5 & $14.3 \%$ & $50.0 \%$ \\
\multicolumn{1}{c}{ Total } & 35 & $100.0 \%$ & $350.0 \%$ \\
\hline
\end{tabular}

All the teachers (100\%) mentioned that to teach English, they 'focus on forms and meaning'; they 'provide students with opportunities to develop both accuracy and fluency'; they try 'to integrate grammar with the four skills' and 50\% mentioned that they teach both traditional and communicative grammar. All these strategies are supposed to have the same goal: making real communication the focus of language learning.

Ninety percent $(90 \%)$ of them argued that they integrate grammar in their different tasks and activities and $70 \%$ said it is a complete integration and $40 \%$ found it has been helping students to learn effectively.

However, trying to teach grammar communicatively cannot be an easy task if the Beninese teaching environment is 
to be considered. These teachers were given the opportunities to reveal their challenges. The outcome is unveiled in table 7.

Table 7. Challenges

\begin{tabular}{lcrc}
\hline \multirow{2}{*}{ Challenges } & \multicolumn{2}{c}{ Responses } & Percent \\
\cline { 2 - 3 } & $\mathrm{N}$ & Percent & of Cases \\
\hline Traditional textbooks & 3 & $11.1 \%$ & $33.3 \%$ \\
Communicative tasks difficult to design & 9 & $33.3 \%$ & $100.0 \%$ \\
Lack of appropriate materials & 8 & $29.6 \%$ & $88.9 \%$ \\
More appropriate training needed & 7 & $25.9 \%$ & $77.8 \%$ \\
\multicolumn{1}{c}{ Total } & 27 & $100.0 \%$ & $300.0 \%$ \\
\hline
\end{tabular}

The teachers' first main challenge is the 'difficulty of designing communicative tasks' $(100 \%)$ followed by 'lack of appropriate materials' $(88.9 \%)$ and 'lack of appropriate training' $(77.8 \%)$, and finally 'textbooks more traditional than communicative'. This is the real face of the teaching environment in Benin.

Being aware of one's challenges is not enough. There is need for the respondent teachers to have a clear view of how to overcome them. In other words, making the teaching of English rewarding and consistent with communicative purposes is what they should fight for. Table 8 displays these suggestions.

Table 8. Suggestions

\begin{tabular}{lccc}
\hline \multirow{2}{*}{ Suggestions } & \multicolumn{2}{c}{ Responses } & Percent of \\
\cline { 2 - 3 } & $\mathrm{N}$ & Percent & Cases \\
\hline Nationwide training & 10 & $25.0 \%$ & $100.0 \%$ \\
change of exams format & 10 & $25.0 \%$ & $100.0 \%$ \\
Regular training a priority & 10 & $25.0 \%$ & $100.0 \%$ \\
Provision for teaching materials & 10 & $25.0 \%$ & $100.0 \%$ \\
\multicolumn{1}{c}{ Total } & 40 & $100.0 \%$ & $400.0 \%$ \\
\hline
\end{tabular}

Obviously, all the respondents (100\%) held the views that organizing a nation-wide training for communicative grammar teaching, changing the exams format which is too loaded with prescriptive grammar, making classroom teachers' regular in-service training a priority and creating more provision for teaching materials should be all school stakeholders' duty to fulfill at any cost.

Apart from the questionnaire administration, there is need to use interview and class observation as research instruments to counter-balance the limitations of the former tool.

\subsubsection{Interview Report}

The four interviewees (three teachers and a supervisory staff) were to answer the following questions. (1) How is grammar taught in our EFL classes today? (2) What do you think of communicative grammar teaching generalization in Benin? What suggestions can you offer to make grammar teaching consistent with our students' communicative needs?

The information collected was synthesized and analyzed. The opinions and perceptions about the issue can be summarized as follows:

* the teaching/learning of EFL in Benin and more importantly that of grammar teaching is in a critical situation;

* TG is the commonest method used by the majority of the teachers even by those who claim they are teaching grammar communicatively;

* because of the disadvantages of traditional grammar teaching, learners find it difficult to transfer what they have learnt in classroom to communicate in real life situations. As a result, their learning goals are difficult to reach;

* an educational shift towards CLT is needed that would benefit CBA and pave the way to new pedagogical practices implementation for communication sake; 
* both approaches have advantages and disadvantages; therefore, an eclectic approach should be adopted combining communicative with traditional grammar teaching;

* priority should be set right therefore, training policy should be thoroughly revised.

\subsubsection{Class Observation Report}

The outcome of the two class observations revealed the following.

$>$ Both teachers who were observed used more features of traditional methodology with some imaginative new techniques to teach their sequence of grammar lesson;

$>$ One of the teacher used an inductive while the other the deductive approach;

$>$ As most of the grammar activities in the prescribed textbooks feature the traditional patterns with structural exercises, both teachers found it difficult to integrate their grammar lessons with other skills;

$>$ Though some efforts were made to make the lessons less boring and as interactive as possible, the language used was more classroom language than language meant for communication in real life situations;

$>$ None of the teachers provides a context, let alone any authentic contexts that could have showed when and where a communication can take place in grammar lessons;

$>$ Both teachers' lessons respected the traditional three phases: presentation, practice, and production, usually referred to as the 'PPP' approach;

$>$ One of the teachers seemed to exercise more control than needed and this seemed to stifle students' participation and creativity;

$>$ Both teachers taught grammar lessons as listed in the textbooks.

In sum, it can be noticed that the questionnaire answers provided by the teachers who claim they teach communicative grammar do not support their classroom practice. In other words, the results of the questionnaire about communicative grammar teachers are contradictory to what the researcher eye- witnessed during the class observation sessions.

After the various results collected from different respondents, let us move on to the discussion of all these data.

\section{Discussion}

The present section hinges around the two main research questions this study is supposed to highlight.

1) What are the challenges the teaching of grammar is currently facing in EFL classes in Benin?

2) How far can the teaching of communicative grammar improve the teaching of EFL for effective language use in real life?

\subsection{The Challenges of Grammar Teaching in Benin}

The various results collected from different respondents (students, teachers and supervisory staff) reveal the same reality: grammar teaching in EFL classes in Benin is in a critical situation. Many reasons account for it. The majority of students resent the way grammar is taught to them. They are taught grammatical rules to master sentence patterns but they cannot apply them correctly to communicate in real life situations. Another complaint is the lack of interaction and involvement that make grammar lessons boring and mechanical. In fact, experienced teachers are aware that among the various factors that lead to the understanding process, among which sentence appropriateness in various situations, learning rules is just a small part. Hence the need for teachers to help students reach linguistic competence and be capable of using grammar as an instrument that can generate oral and written discourse in an efficient, effective, and appropriate way according to the situation. [Lewis, (1986)]

Nearly half of the respondent teachers (44.44\%) who have opted for TG confessed that their main reasons are: they are either the end-products of this approach or they are just ignorant of the communicative grammar teaching, or because it prepares students better for success in national exams and tests. Priority should be set right as we live in a globalized world that imposes new customs, new beliefs, new conceptions of life etc. So, everything teachers teach today in this field should allow learners to use different grammatical structures studied in class in various contexts for communication purposes outside the class. In other words, they should avoid making it a knowledge transmission process but rather a skills development. Larsen-Freeman $(1997 ; 2001)$ called it grammaring rather than grammar. She argues that by considering grammar as a skill to master, students stand the chance of achieving accuracy by 
conveying meaning appropriately.

The results of the students' interview unveil their disappointment in the methodology used by most of the teachers. It is fortunate that the respondent teachers themselves are also aware of the challenges they have been facing in their day-to- day routine of grammar teaching. All of them $(100 \%)$ realized that their learners face a lot of hurdles. In fact, with regard to the type of grammar deems appropriate to EFL students' effective learning, teachers need to take account of the following factors suggested by Celce-Murcia (1991). Firstly, students' learning style should not be overlooked: some are analytical thinkers while some are systematic ones and as a result, with different strengths, abilities and shortcomings as well. Therefore, to help learners gradually develop their learning strategies so as to use the target language confidently, teachers should strive to balance their classroom activities with various student intelligences. Secondly, the age of the learners is another determinant factor teachers should focus on as far as forms are concerned. Children and even adolescents learners, should be given little explicit grammar rules while more mature students need some explicit focus on forms. The results of this study seem to support this views as more first cycle students in comparison with mature second cycle students found traditional grammar having some advantages to benefit from (Figure 1). Thirdly, the proficiency level of learners is another factor to be considered. It means that advanced learners need more individualized materials for rewarding results to be expected. But unexpectedly, the same young respondent students in this study show more reasons to dislike traditional grammar than mature students. It simply means that though traditional grammar offers better chance to get better grades in tests and in national exams, they are aware that their communicative needs should be given priority and they are not being met with this approach. Fourthly, the learners' educational background is another identified factor. Because it is influenced by culture, some learners require to be taught grammar rules because it meets their cultural expectations. This may not be the case of Beninese students because with the advent of the Competency-Based Approach (CBA) more and more autonomy is gradually given to students to build their own knowledge and be responsible for their own learning. Fifthly, the educational objectives are other assets EFL teachers need to decide upon: what to focus on in grammar. If for example receptive skills (listening and reading) are the emphasis, teachers may focus on forms, whereas if the productive skills (speaking and writing) and fluency are students' goals or needs, teachers should put emphasis on formal accuracy. Most Beninese students learn English for a general purpose but more importantly for communicative competence, that is the ability to convey their oral and written message efficiently, effectively and appropriately; a view that considers language learning as a life-long process rather than an occasional business to prepare students for tests and exams.

However, both observed teachers seem eager to let their learners use the new taught forms to describe their own ideas, experiences, and generally to create meaning using the form they have just learned. But, not only are the exercises in the textbooks inappropriate as most of the respondent teachers complained about, but the teachers themselves seem not to have the professional grounding needed to perform the job because the training situation of teachers in Benin is far from being glowing. As Borg $(1998, \mathrm{p} .17)$ contends, the use of a particular teaching technique, approach, or methodology is most of the time influenced by the idea of making students enjoy grammar, and apply rules in a practical and updated way, using context-based methodologies for effective learning. This calls for the teacher's constant search for innovation, making his classes dynamic, inspiring and stimulating even when he is himself an end-product of another contrasting traditional method.

Implementing effective and rewarding teaching strategies that is likely to guide, help, and persuade students to view grammar as an efficient tool for language competence should be the goal of every teachers in Benin. But, only a trained teacher who has opted for self-professional development and as a result, is in a constant quest for alternative teaching strategies and ready to spark learners' interests by making the teaching of grammar a challenging and rewarding experience can be such a candidate.

\subsection{Teaching Communicative Grammar (CG) for Effective Language Use in Real Life Situations}

The question of knowing how far the teaching of CG can improve the teaching of EFL for effective language use in real life is of paramount importance. The results of the survey reveal that younger instructors who claim to teach communicative grammar have good reasons to choose this approach for it offers better chance to students to speak English. But unexpectedly, the class observation results do not seem to support the questionnaire results and consequently what it requires to achieve this goal. In fact, according to many researchers, the main objective of CLT is the teaching of communicative competence which refers to how and when to use language for a wide range of purposes and functions; for instance making out between formal and informal discourse, between written and spoken communication, producing and understanding different types of texts and ultimately being communicatively efficient. 
However, to the question of 'How do you teach grammar?' all the respondent teachers who claimed they teach CG mentioned that they 'go beyond sentence level to focus on forms and meaning'; they 'provide students with opportunities to develop both accuracy and fluency' and also they 'try to integrate grammar with other skills'. All these look like fine resolutions that require practical application at the classroom level and later in real life situations. For this to be possible, teachers should be able to substitute traditional activities such as accurate repetition, rote-learning of phrases, sentence patterns and grammatical rules and drills, to activities that require learners to organize their knowledge about language, exploiting available information, solving problem-based situations, using and displaying critical sense, working in cooperation, interacting with peers, defending viewpoints and communicating in a precise and appropriate way. No wonder that supervisory staff and Beninese teachers as well are aware that methodological shift is unavoidable today but still needs what it requires to meet up with the new challenge. This shift may require to make CLT the real support or basis for CBA so as to help improve the mastery of the language by all means.

Fifty percent $(50 \%)$ of the sampled teachers mentioned they use both traditional and communicative grammar. Does it mean that teachers should gradually discard TG and adopt CG alone? To be consistent with the way grammar is viewed today, that is teaching grammar to enable learners to use linguistic forms accurately, meaningfully and appropriately, both approaches should not be considered mutually exclusive. It means providing students with opportunity to produce grammatical structures skillfully for communicative purposes, a goal that requires significant and meaningful practice. As the ineffectiveness of mechanical practice is a glaring reality, there is need to design or select activities that encourage meaningful practice; and that is where the shoes pinch. Designing communicative grammar activities is a real challenge for any untrained teacher in a 'textbook and chalk' context which characterizes this part of the world called Benin.

In most Beninese textbooks, grammar activities feature the traditional pattern and do not conform to the principles of the communicative syllabus. Most exercises are mainly structural and focus on grammar rules explanation with mechanical practice. Therefore, there is an urgent need to supplement these structural activities with communicative activities by using authentic materials. It means planning more communicative, interactive and dynamic oral activities such as role-plays, oral presentations, impromptu speeches, dialogues, pair and group conversations and keeping the right balance between meaningful written and oral activities. By doing so, students will see the relevance of grammar and how it is used in real life contexts. As a result, they will gain competence in the use, transfer and applicability of the language, making rules and meaning two major complementary components they need to develop. This view is also supported by Chang (2000) who suggested five types of activities: games, natural contexts, activities that balance skills, personalization and adjustment of teacher role.

\subsection{Strategies for Implementation}

The real challenge of EFL teachers today and mainly Beninese teachers is finding strategies to make grammar classes interactive, creative, stimulating and productive. This is not an easy task in this context if we know that lack of adequate training compounded by lack of materials are not incentives for these language teachers who need to develop and implement catchy activities to provoke learners' enthusiasm, interest and motivation. But because many Beninese EFL teachers today, relatively young in the profession are ready to shrug off odds and fight for professional breakthrough, it is worthwhile providing teachers with some down-to-earth activities that incorporate real life situations. Some of these activities proposed by various specialists can make grammar classes enjoyable, more fun and task-oriented for students' delight. Examples can be these:

* Using modals to give advice: students might be asked to play the role of an advice columnist. They are given opportunity to write a column about an interesting topic and then give advice to a classmate who is having a particular problem about the issue. They might also role play having a 'dilemma' (locking the car key inside the car at a picnic for example). Having students work on such structures in writing and speaking activities can highlight differences between written and oral grammars (Doughty and William 1998).

* The teacher may give students a newspaper article in English. He asks students to identify the tenses, keywords, simple and complex sentences, use of connectors and analysis of discourse patterns. This task will help students anticipate the forms and structures the text will have since it follows a predictable format. This will develop their predictive skills.

* The teacher asks students to match grammatical patterns to particular communicative meanings and the learners choose the right pattern to express ideas and feelings about a particular topic. This will help them use grammar to express different communicative meanings; they can thus see the connection between form and function. 
* The teacher engages the students in a short discussion about an issue related to their own lives using a grammar structure content and their background knowledge. Through referential questions the teacher will provide materials for interactive and dynamic discussion, while students negotiate meaning and review grammar forms that will ultimately lead to genuine communication.

* One of the notorious challenges for EFL/ESL students is to have a clear view about when to use the present perfect versus when to use the past tense. This can be exemplified by a job interview situation. In such a context, a possible question might be for example 'Have you ever done any secretary job or computer work? An affirmative answer is likely to be 'Yes, I have. I once worked in...... or when I worked at...... The role of interviewer and interviewee will be played by students in turn. The social and linguistic discourse contexts will be the two determinant components that will help learners make the right appropriate choice. (Larsen-Freeman, 2001).

All these suggestion actions are aimed at moving along the recent advancement in language teaching to meet students' needs, goals and interests. However, one might ask what can be the implications of this new suggested change in Beninese context. As Borg (1998) rightly puts it, the use of a particular teaching technique, approach or methodology is influenced by the language teacher's educational background, and by the formal training that this teacher had. As a result, a teacher whose educational background is firmly molded by the traditional approach to grammar teaching will be reluctant or at least not confident enough to venture boldly on this apparently 'new' field as some of our respondent teachers confessed. In crossing the line to view grammar as a skill, and communicative grammar teaching as an attempt to apply both a form of description and methodological practices which reflect a process view of grammar, the teacher is therefore confronted with a system that contradicts the mighty weight of tradition. Conversely, when the teacher is firmly influenced by the idea of making grammar classes fun and enjoyable he will apply rules in a practical and update way for students genuine interaction just like in a real life situation.

This requires certain flexibility and willingness as well as the questioning of traditional grammar dogma. A nation-wide training about the issue supported by regular in-service training, and a change in national exams format too heavily loaded with prescriptive grammar is compulsory. This will gradually help teachers implement effective and useful teaching methodologies likely to persuade students to consider grammar as an efficient instrument for their idea transfer in a clear, precise and appropriate way.

Therefore, the main implication of this study is that, it stands the chance of giving grammar teaching/learning in Benin a new vision and a new thrust that assign to it a new role with a different perspective that leads to a more challenging and rewarding experience in communicating with the language. No doubt, true change after decades of practice cannot happen overnight, but teachers are supposed to be agents of change and be ready to be creative and innovative.

\section{Conclusion}

This study has set the noble ambition of exploring the teaching of communicative grammar in EFL classes in Benin for more language practice. In fact, teaching grammar requires more than a pedagogical practice that provides accuracy, explicit rules rote-learning and application of grammatical forms.

The results of the survey reveal that not many teachers in Benin teach CG and those who claim they teach it, still have a lot to learn to expand their knowledge to be able to impact learners' communicative skills. Therefore, some tasks likely to engage students in interactive activities just like in real life are suggested. The main objective is that grammar classes can be made fun and catchy. For this to happen, teachers should be made aware that rules and meaning are both complementary key components which develop effective language practice. In other words, both communicative language teaching and traditional grammar teaching are not mutually exclusive, but rather represent the two faces of the same coin. More importantly, a potential finding in this study is that CBA can benefit from CLT because not only do both follow a socio-constructivist framework, but CLT has a long history of fruitful research that CBA can tap from for its effective implementation.

\section{References}

Borg, S. (1998). Teachers' Pedagogical Systems and Grammar Teaching: A Qualitative Study. TESOL Quaterly, 32(1), 9-38.

Brown, H. W. (2001). Teaching by Principles: An Interactive Approach in Language Pedagogy. White Plain, New 
York: Addison Wesley Longman, Inc.

Celce-Murcia, M. (1991). Grammar Pedagogy in Second and Foreign Language Teaching. TESOL Quaterly, 25(3), 459-477. https://doi.org/10.2307/3586980

Chang, S. J. (2000). No More English-Savvy Dummies or Fluent Fools: A Communicative Approach of Teaching English Conversation. English Teaching and Learning, 25(1), 40-59.

DIP (Direction de L'Inspection Pédagogique) (2010). Formation des Professeurs sur l'Enseignement Secondaire General à la Mise en Euvre des Principes de l'Evaluation des Apprentissages selon l'Approches par Compétences. De Ketele, J. M. Observer pour Eduquer, Bruxelles: De Boeck.

Doughty, C., \& J. Williams, eds. (1998). Focus on Forms in Classroom Second Language Acquisition. Cambridge: Cambridge University Press.

Ellis, R. (1995). The Study of Second Language Acquisition. Oxford: Oxford University Press.

Ellis, R. (2006). Current issues in the teaching of Grammar: An SLA perspective. TESOL Quarterly, 40(1), 83-107. https://doi.org/10.2307/40264512

Harmer, J. (1997). Teaching and Learning Grammar. London; New York: Longman.

Howatt, A. P. R. (1984). A History of English Language Teaching. Oxford: Oxford University Press.

Krashen, S. (1985). The Input Hypothesis: Issues and Implications. New York: Longman.

Kvale, S. (2007). Doing interviews. London: Sage. https://doi.org/10.4135/9781849208963

Larsen-Freeman, D. (1991). Teaching Grammar. In M. Celce-Murcia (Ed.), Teaching English as a Second and Foreign Language. New York: Harper \&Row/ Newbury House.

Larsen-Freeman, D. (2001). Teaching Language: From Grammar to Grammaring. Boston, MA: Heinle \& Heinle.

Lewis, M. (1986). The English Verb: An Exploration of Structure and Meaning. UK: Language Teaching Publication.

Lock, G. (1997). Functional English Grammar: An Introduction for Second language Teachers. Cambridge: Cambridge University Press.

Lopez, J. R., \& Agullo, G. L. (2012). The Role of Grammar Teaching: From Communicative Approaches to the Common European Framework of Reference for Languages. Revista de Linguistica y Lengua Aplicadas, 7 , 179-191.

Littlewood, W. (1981). Communicative Language Teaching. Cambridge: Cambridge University Press.

Newby, D. A. (2006). Teaching grammar and the question of knowledge. In A. B. Fennerand and D. Newby (eds.), Coherence of Principles, Cohesion of Competences: Exploring Theories and designing Materials for Teacher Education. Graz/Strasbourg: European Centre for Modern Languages/ Council of Europe Press.

Rama, J. L., \& Agullo, G. L. (2012). The Role of Grammar Teaching from Communicative Approaches to the Common European Framework of reference for Languages. Revista de Linguistica y Lenguas Aplicadas, 7. http://dx.doi.org./10.4995/rlyla.2012.1134

Richards, J. (2006). Communicative Language teaching Today. Cambridge: Cambridge University Press. Retrieved from http://www.professoriackrichards.com/pdfs/communicative- language-teaching-today

Richards, J. C., \& Rodgers, T. (2010). Approaches and Methods in Language Teaching: Description and Analysis. Cambridge: Cambridge University Press.

Rutherford, W. E. (1996). Second Language Grammar: Learning and teaching. London, New York: Longman.

Skehan, P. (1996). A framew8ork for the implementation of task-based instruction. Applied linguistic, 17(1), 38-62. https://doi.org/10.1093/applin/17.1.38

Shekan, P. (1998). A Cognitive Approach to language Learning. Oxford: Oxford University Press.

Scott, D., \& Usher, R. (2006). Researching Education: Data, Methods and Theory in Educational Enquiry. London, UK: Continuum International Publishing Group.

Thornbury, S. (1999). How to Teach Grammar. Harlow: Longman.

Ulrich, V. (1994). Are Communicative and grammatical Skills more Effectively Acquired in a traditional or Differentiated Beginning Level Foreign Language Classroom? Thesis. Emporia State University. Retrieved from http://soar.wichita.edu/dspace/bitstream/handle/10057060/t08037 